\title{
EFFECT OF $\kappa$-CARRAGEENAN AND NaCl ON INITIAL FREEZING POINT OF EGG AND SURIMI
}

\author{
D. KOVAČEVIĆa and Ž. KURTANJEK ${ }^{b}$ \\ ${ }^{a}$ Faculty of Food Technology, University of Osijek, F. Kuhača 18, HR-31000 Osijek. Croatia \\ ${ }^{b}$ Faculty of Food Technology and Biotechnology, University of Zagreb, Pierottijeva 6, \\ HR-10000 Zagreb. Croatia
}

(Received: 24 January 2000; accepted: 14 June 2000)

Initial freezing points $T_{\mathrm{i}}$ of egg samples (melange of egg yolk and white, egg yolk, egg white) and surimi mixed with different mass fractions of $\mathrm{K}$-carrageenan $(w=1-10 \%), \mathrm{NaCl}$ $(w=1-10 \%)$, and mixtures of $\mathrm{NaCl}$ and $\kappa$-carrageenan in mass ratio of $4: 1(w=1-10 \%)$ were determined by use of differential thermal analysis (DTA). Samples of surimi were prepeared in laboratory conditions from Sardina pilchardus. Water content in surimi was $81.50 \%$, in egg yolk $47.65 \%$, in egg white $88.1 \%$, and in melange it was $64.41 \%$ before mixing with the added substances.

Relations between decrease of the initial freezing point $T_{\mathrm{i}}$ as function of mass fractions $w$ of the added substances were determined by linear regression. Coefficients of determination in range of $R^{2}=0.94-0.98$ for samples of surimi, and $R^{2}=0.92-0.98$ for samples of egg were obtained. The largest effect of cryoscopic depression on initial freezing point $T_{\mathrm{i}}$ were exhibited by the samples of surimi with added: a) $\mathrm{NaCl}$ in the temperature range from -0.19 to $-11.11^{\circ} \mathrm{C}$, b) mixtures of $\mathrm{NaCl}$ and $\mathrm{k}$-carrageenan (from -0.19 to $-9.08^{\circ} \mathrm{C}$ ), and c) $\mathrm{k}$-carrageenan (from -0.19 to $-0.72{ }^{\circ} \mathrm{C}$ ). For the samples with pure $\mathrm{NaCl}$ the largest decrease of $T_{\mathrm{i}}$ was obtained for: a) egg yolk (from -0.59 to $-20.77^{\circ} \mathrm{C}$ ), b) melange (from -0.59 to $-8.74^{\circ} \mathrm{C}$ ), and c) egg white (from -0.50 to $-7.37^{\circ} \mathrm{C}$ ). The results are compared and discussed with Chang-Tao model for prediction of $T_{\mathrm{i}}$ for meat.

Keywords: initial freezing point, DTA, surimi, egg, $\mathrm{NaCl}$, $\kappa$-carrageenan

Thermal properties of food are important for determination of process parameters, design of process units and technology development and for effective performance of unit operations with heat transfer. In the preservation of food by freezing, a minimal mass fraction of $50 \%$ of water is, in the temperature-range below $T_{\mathrm{i}}$, transformed to ice. The significant difference of thermal properties of water and ice results in a significant change in thermal properties of food during freezing (for example thermal conductivity is $k$ (ice) $=2.210 \mathrm{~W} \mathrm{~m}^{-1} \mathrm{~K}^{-1}$, while $k$ (water) $=0.5815 \mathrm{~W} \mathrm{~m}^{-1} \mathrm{~K}^{-1}$, specific heat capacities at constant pressure are $c_{p}$ (water) $=4.187 \mathrm{~kJ} \mathrm{~kg}^{-1} \mathrm{~K}^{-1}$ and apparent $c_{p}$ (ice) $=2.098 \mathrm{~kJ} \mathrm{~kg}^{-1} \mathrm{~K}^{-1}$, and thermal diffusivities are $\alpha$ (water) $=5.210^{-4} \mathrm{~m}^{2} \mathrm{~h}^{-1}$, 
apparent $\alpha$ (ice) $=410^{-3} \mathrm{~m}^{2} \mathrm{~h}^{-1} \quad$ (GRUdA \& POSTOLSKI, 1980). Most of the mathematical models for prediction of thermal properties of frozen food are based on the equation for cryoscopic depression of initial freezing point $T_{\mathrm{i}}$ (HELDMAN, 1982; SCHWARTZBERG, 1976; 1983; CHANG \& TAO, 1981; CHEN, 1985; 1986), $\Delta \mathrm{T}=\mathrm{K}_{k} \cdot \gamma(\Delta \mathrm{T}$ is temperature decrease, $K_{k}$ is cryoscopic constant, $\gamma$ is molality). The experimental methods most frequently used for determination of $T_{\mathrm{i}}$, are differential scanning calorimetry (DSC) and differential thermal analysis (DTA) which are according to "ICTA" (Nomenclature Committee of the International Confederation for Thermal Analysis) the methods which are based on the change of apparent enthalpy (FINDLAY \& BARBUT, 1990). The methods for measurement have to account for time delay of temperature sensors (large time constant), lack of standardisation of measurement methods and conditions, problem with sample homogenisation and preparation and specifically the problem with small samples (SWEAT \& HAUGH, 1974; 1976). The advantages of DTA method are: negligible thermal gradient in samples, rate of temperature change does not effect the accuracy of measurement of $T_{\mathrm{i}}$ and enables the use of larger samples of food with solid particles.

In this work laboratory design of DTA apparatus was applied for determining $T_{\mathrm{i}}$ of samples of egg (melange of egg yolk and white, egg yolk, egg white) and surimi mixed with different mass fractions of $\kappa$-carrageenan $(w=1-10 \%), \mathrm{NaCl}(w=1-10 \%)$, and mixtures of $\mathrm{NaCl}$ and $\kappa$-carrageenan in mass ratio of $4: 1(w=1-10 \%)$. Application of linear regression was examined for determination of functional relationship between mass fraction of added substances $w$ and initial freezing point $T_{\mathrm{i}}$.

\section{Materials and methods}

\subsection{Materials}

Samples of surimi were prepared in laboratory from Adriatic pilchard (Sardina pilchardus) according to technique by LEE (1984) with details given by SYCH and co-workers (1990). Samples were divided into three groups and each was mixed respectively with: a) $\kappa$-carrageenan; b) $\mathrm{NaCl}$; c) $\mathrm{NaCl}$ and $\kappa$-carrageenan in mass ratio of $4: 1$. Mass fractions were in the range of 0 to $10 \%$ determined as percent of total mass. Moisture content was $81.50 \%$ determined by the A.O.A.C. method (1980) for meat products before addition of the added components. Total protein mass fraction was $16.30 \%$ determined with $1 \mathrm{~g}$ samples by Kjeldahl method; (Kjeltec System, model 1002 Distilling Unit). Samples were packaged in polyethylene bags and quickly frozen in liquid nitrogen and stored at $-25^{\circ} \mathrm{C}$. Average storage time was 1 week before experimental treatment. 
Samples of egg were prepared from three days old chicken eggs produced at an industrial farm. The samples were divided into three groups: egg yolk, egg white, melange of egg yolk and white, and were mixed with $\mathrm{NaCl}$ in different mass ratios. The mass fractions of $\mathrm{NaCl}$ in egg yolk were $w=1,4,6,8$, and $10 \%$, in egg white $w=2,4$, 6,8 , and $10 \%$, and in the melange $w=1,3,6,8$, and $10 \%$. Water content was determined by A.O.A.C. method (1980) for egg and egg products, and was for egg yolk samples $47.65 \%$, in egg white $88.01 \%$, and in melange $64.41 \%$. Total protein mass fraction was determined with $1 \mathrm{~g}$ samples by Kjeldahl method; (Kjeltec System, model 1002 Distilling Unit), and obtained to be $17.80 \%$ for egg yolk, $10.71 \%$ for egg white, and $12.02 \%$ for melange. Samples were packaged in polyethylene bags and quickly frozen in liquid nitrogen and stored at $-25^{\circ} \mathrm{C}$. Average storage time was 1 day before experimental treatment.

\subsection{Methods}

DTA apparatus was constructed in the laboratory (KOVAČEVIĆ \& KURTANJEK, 1993) and was used for measurement of inital freezing point $T_{\mathrm{i}}$. Thermocouples were made from Alumel-Chromel wires with a diameter of $0.07 \mathrm{~mm}$. The standard error in calibration was $50 \mathrm{mK}$ with sensitivity of $10 \mathrm{mK}$. The instruments were interfaced with a standard PC and sampling rate of $3.5 \mathrm{kHz}$ was used. All data were prefiltered with $3 \mathrm{~s}$ rule for noise rejection prior to data analysis. Aqueous solution of $\mathrm{CaCl}_{2}$, $w\left(\mathrm{CaCl}_{2}\right)=30 \%$, was used as reference substance for DTA measurement. Distilled water was used as calibration substance for the static correction of the initial freezing point.

\section{Results}

DTA measurements of samples of surimi, melange, egg white, and egg yolk mixed with the added substances (total 49 samples) were conducted in temperature range from -25 to $5{ }^{\circ} \mathrm{C}$. In Fig. 1 the results of DTA for surimi samples mixed with $\kappa$-carrageenan are presented, and in Fig. 2 results of DTA for samples of melange mixed with $\mathrm{NaCl}$ are presented.

The DTA curves have a low level of measurement noise, which is a result of statistical data filtering and rejection of outliers by $\pm 3 \sigma$ rule, and is due to high frequency of data sampling. Drift from the base line in the temperature range from 0 to $0.2^{\circ} \mathrm{C}$ is due to difference of thermal properties of samples and the reference substance.

From DTA diagrams the peak points were read off as the initial freezing points. Data for the initial freezing points $T_{\mathrm{i}}$ are given in Table 1. 


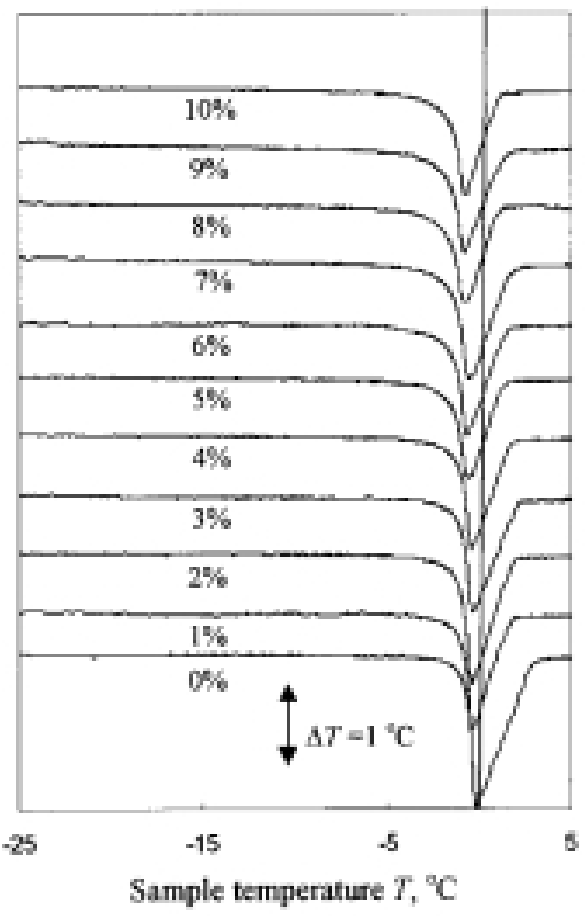

Fig. 1. DTA curves of surimi as a function of mass fraction of $\kappa$-carrageenan. $\Delta T$ is the temperature difference between sample and reference substance

In Figs 1 and 2 systematic shifts of the initial freezing points can be observed toward lower temperatures with increased concentration of added substances. Below the initial freezing points DTA diagrams for all samples show systematic increase in the temperature difference with increased level of the added substances.

Each DTA diagram is corrected only for constant error of $+0.045^{\circ} \mathrm{C}$ which was determined from calibration with distilled water. By the method of linear regression of $T_{\mathrm{i}}$ to mass fraction of the added substances the parameters of the regression equation were determined:

$$
T_{\mathrm{i}}=a+b \cdot w
$$

$a$ and $b$, standard errors $e(T)$ and coefficient of determination $R^{2}$. Parameters of the regression models (1) are given in Table 2. 


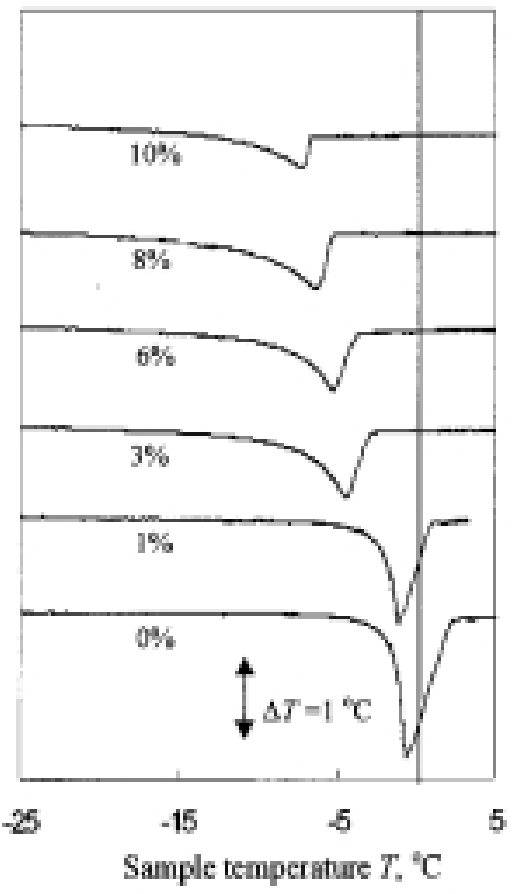

Fig. 2. DTA curves of melange as a function of mass fraction of $\mathrm{NaCl} . \Delta T$ is the temperature difference between sample and reference substance

The difference in the slopes of linear regressions is in accordance with the equation of cryoscopic freezing point decrease which is inversely proportional to the molecular mass of dissolved substances.

The most pronounced effect of cryoscopic depression on initial freezing point $T_{\mathrm{i}}$ is exhibited by the samples of surimi with added: a) $\mathrm{NaCl}$ in the temperature range from -0.19 to $-11.11^{\circ} \mathrm{C}, \mathrm{b}$ ) mixtures of $\mathrm{NaCl}$ and $\mathrm{\kappa}$-carrageenan in mass ratio of $4: 1$ (from -0.19 to $-9.08{ }^{\circ} \mathrm{C}$ ), and c) $\mathrm{K}$-carrageenan (from -0.19 to $-0.72{ }^{\circ} \mathrm{C}$ ). For the samples with pure $\mathrm{NaCl}$ the highest decrease of $T_{\mathrm{i}}$ was obtained for: a) egg yolk (from -0.59 to $-20.77^{\circ} \mathrm{C}$ ), b) melange (from -0.59 to $-8.74^{\circ} \mathrm{C}$ ), and c) egg white (from -0.50 to $\left.-7.37{ }^{\circ} \mathrm{C}\right)$. 
Table 1

Experimental data of initial freezing point $T_{i}$

\begin{tabular}{|c|c|c|c|c|c|c|}
\hline \multirow{2}{*}{$\begin{array}{l}\text { Mass fraction } \\
\text { of added } \\
\text { substances } \\
w, \%\end{array}$} & \multicolumn{6}{|c|}{ Initial freezing point $T_{\mathrm{i}},{ }^{\circ} \mathrm{C}$} \\
\hline & $\begin{array}{c}\text { Surimi }+ \\
\kappa-\text { carrageenan }\end{array}$ & $\begin{array}{c}\text { Surimi }+ \\
\mathrm{NaCl}\end{array}$ & $\begin{array}{c}\text { Surimi }+ \\
\text { mixture of } \mathrm{NaCl} \\
\text { and } \kappa \text {-carrageenan } \\
\text { in mass ratio of } 4: 1\end{array}$ & $\begin{array}{l}\text { Egg white + } \\
\mathrm{NaCl}\end{array}$ & $\begin{array}{c}\text { Egg yolk }+ \\
\mathrm{NaCl}\end{array}$ & $\begin{array}{c}\text { Melange + } \\
\mathrm{NaCl}\end{array}$ \\
\hline 0 & -0.19 & -0.19 & -0.19 & -0.50 & -0.59 & -0.59 \\
\hline 1 & -0.30 & -1.02 & -0.81 & & -1.00 & -1.94 \\
\hline 2 & -0.33 & -2.01 & -1.85 & -2.00 & & \\
\hline 3 & -0.33 & -2.52 & -2.78 & & & -4.50 \\
\hline 4 & -0.37 & -3.48 & -3.43 & -4.10 & -6.80 & \\
\hline 5 & -0.52 & -4.08 & -3.58 & & & \\
\hline 6 & -0.58 & -5.45 & -5.15 & -4.85 & -7.65 & -5.30 \\
\hline 7 & -0.53 & -6.40 & -5.07 & & & \\
\hline 8 & -0.73 & -7.05 & -6.69 & -5.87 & -12.01 & -7.22 \\
\hline 9 & -0.75 & -8.68 & -7.10 & & & \\
\hline 10 & -0.72 & -11.11 & -9.08 & -7.37 & -20.77 & -8.74 \\
\hline
\end{tabular}

Table 2

Parameters of the regression models (1) for initial freezing point $T_{i}$

\begin{tabular}{|c|c|c|c|c|c|}
\hline Samples & $\begin{array}{l}\text { Added substances } \\
\qquad(w=1-10 \%)\end{array}$ & $b$ & $a$ & $e(T)$ & $R^{2}$ \\
\hline \multirow[t]{3}{*}{ Surimi } & $\mathrm{NaCl}$ & -1.0007 & 0.27250 & 0.0590 & 0.97 \\
\hline & $\begin{array}{l}\kappa \text {-carrageenan } \\
\text { mixture of } \mathrm{NaCl} \text { and }\end{array}$ & -0.0571 & -0.20616 & 0.0048 & 0.94 \\
\hline & $\kappa$-carrageenan in mass ratio of $4: 1$ & -0.8219 & -0.05168 & 0.0426 & 0.98 \\
\hline Egg white & $\mathrm{NaCl}$ & -0.6608 & -0.82570 & 0.0439 & 0.98 \\
\hline Egg yolk & $\mathrm{NaCl}$ & -1.8470 & 0.79084 & 0.2698 & 0.92 \\
\hline Melange & $\mathrm{NaCl}$ & -0.7611 & -1.16324 & 0.0715 & 0.97 \\
\hline
\end{tabular}

If $T_{\mathrm{i}}$ of surimi and egg samples with the same mass fraction of $\mathrm{NaCl}$ are compared, the highest cryoscopic depression is observed in the following order: egg yolk, surimi, melange and egg white. The results confirm the assumption that $T_{\mathrm{i}}$ is not a function of the mass fraction of water only. It can be assumed that $T_{\mathrm{i}}$ is determined by the mass fraction and type of proteins and intensity of interaction between water and $\mathrm{NaCl}$ and proteins. 
In Figs 3 and $4 T_{\mathrm{i}}$ by Chang-Tao model is presented (CHANG \& TAO, 1981), given by the linear regression equation with respect to mass fraction of water $w_{w o}$ :

$$
T_{\mathrm{i}}=1.47 \cdot w_{w o}-1.97
$$

The experimental value for $T_{\mathrm{i}}$ and results by the Chang-Tao model (2) show large deviations. The most important differences for $T_{\mathrm{i}}$ were exhibited for samples with large mass fraction of dry matter. It can be concluded that for complex polydispersed systems, the effect of mass fraction is not the only parameter, but also specific components are important, which require experimental determination.

In Fig. 5 a comparison of dependencies of $T_{\mathrm{i}}$ is presented for melange, egg white, egg yolk, and water solution of $\mathrm{NaCl}$ on mass fraction of $w \mathrm{NaCl}$ calculated on total mass of water. The good agreement for $T_{\mathrm{i}}$ can be attributed to the assumption of weak interaction between water and $\mathrm{NaCl}$ and dry matter of egg.

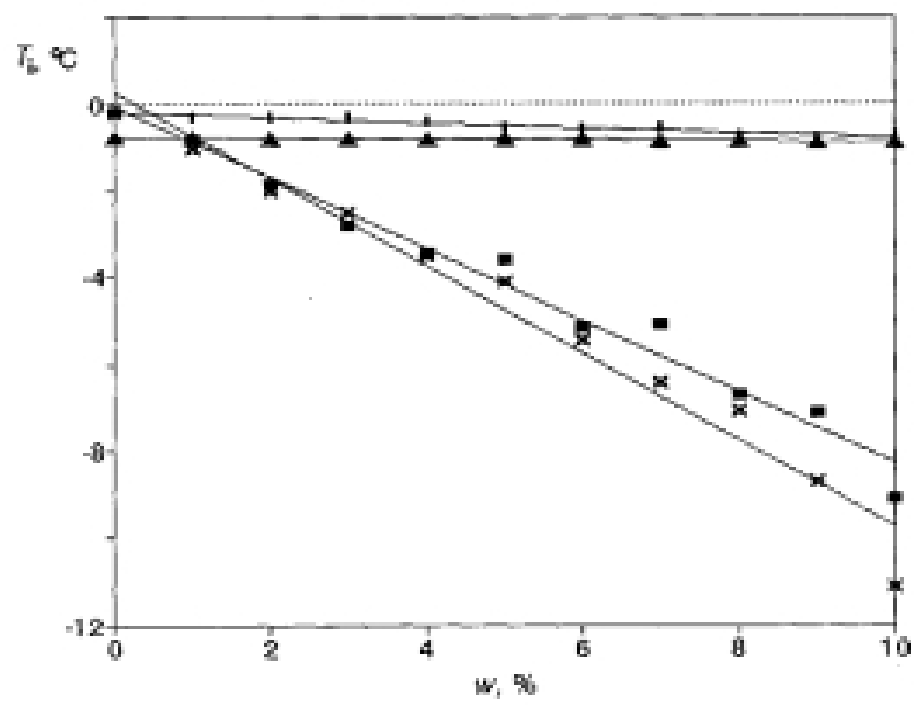

Fig. 3. Initial freezing points $T_{\mathrm{i}}$ of surimi as functions of mass fractions $w$ of the added substances. …: $\kappa$-carrageenan; $\times$ : NaCl; $\mathbf{m}:$ k-carrageenan $+\mathrm{NaCl} ; \mathbf{\Delta}$ : Chang-Tao model; —: linear regression 


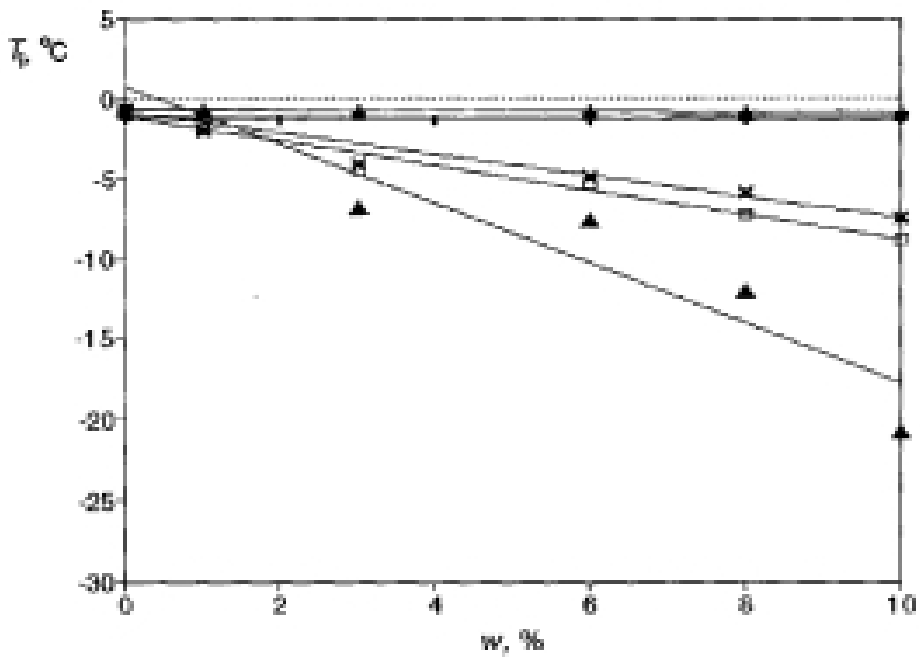

Fig. 4. Initial freezing points $T_{\mathrm{i}}$ of melange, egg white and egg yolk as functions of mass fractions $w$ of the $\mathrm{NaCl}$. +: Chang-Tao model for egg white; $\mathbf{m}$ : Chang-Tao model for melange; $\square$ : melange; $\cdots .$. : Chang-Tao model for egg yolk; $\times$ : egg white; $\mathbf{\Lambda}$ : egg yolk; —: linear regression

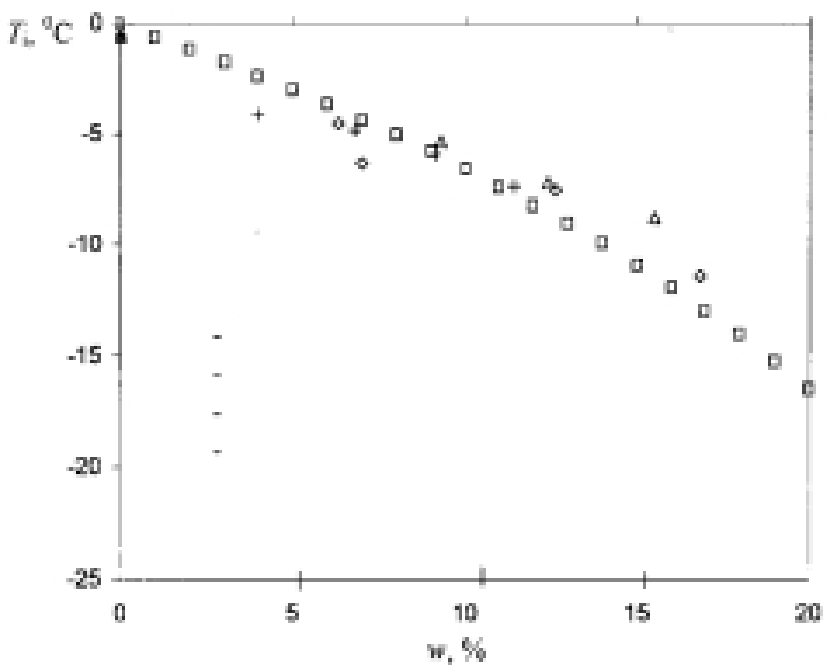

Fig. 5. Comparison of dependencies of $T_{\mathrm{i}}$ for melange, egg white, egg yolk, and water solution of $\mathrm{NaCl}$ on mass fraction of $w \mathrm{NaCl}$ calculated on total mass of water. $\square$ : Water solution of $\mathrm{NaCl} ; \Delta$ : melange; $\diamond$ : egg yolk; +: egg white 


\section{Conclusions}

Cryoscopic depression of initial freezing point of surimi and egg (egg yolk, egg white, melange) is a linear function of the increase of mass fraction of added substances: $\mathrm{NaCl}$, mixtures of $\mathrm{NaCl}$ and $\mathrm{\kappa}$-carrageenan in mass ratio of $4: 1$, and $\mathrm{\kappa}$-carrageenan.

Maximum decrease of the initial freezing point is observed for samples of egg yolk mixed with $\mathrm{NaCl}$ (from -0.59 to $-20.77^{\circ} \mathrm{C}$ ), and the least pronounced effect for samples of surimi with $\mathrm{K}$-carrageenan (from -0.19 to $-0.72{ }^{\circ} \mathrm{C}$ ).

Comparison of the initial freezing points $T_{\mathrm{i}}$ for samples of egg yolk, egg white, melange and water solution of $\mathrm{NaCl}$ as a function of mass fraction of $\mathrm{NaCl}$ calculated on total mass of water in respective samples show good agreement.

This result (i.e. the observed fact) supports the assumption that in the process of the freezing the interaction of dry matter of egg and $\mathrm{NaCl}$ is negligible.

Chang-Tao model of $T_{\mathrm{i}}$ as a linear function of mass fraction of water is not applicable for samples of surimi with addition of $\mathrm{NaCl}$, mixtures of $\mathrm{NaCl}$ and $\kappa$-carrageenan in mass ratio of $4: 1$ and $\kappa$-carrageenan.

Initial freezing point $T_{\mathrm{i}}$ of complex polydispersed systems is not only a function of dry matter, but properties of substances which compose dry matter must also be considered.

This work was financially supported by the Ministry of Science and Technology, Republic of Croatia, project 058201

\section{References}

A.O.A.C. (1980): Official methods of analysis, 13th ed., Arlington, Virginia, pp. 275-376.

CHANG, H. D. \& TAO, L. C. (1981): Correlation of enthalpies of food systems. J. Fd Sci., 46, 1493-1497.

CHEN, C. S. (1985): Thermodynamic analysis of the freezing and thawing of foods: Enthalpy and apparent specific heat. $J$. Fd Sci., 50, 1158-1162.

CHEN, C. S. (1986): Effective molecular weight of aqueous solutions and liquid foods calculated from the freezing point depression. $J$. Fd Sci., 51, 1537-1539.

FINDLAY, C. J. \& BARBUT, S. (1990): Thermal analysis of meat. - in: HARWALKAR, V. R. Ma, C. Y. (Eds) Thermal analysis of foods. Elsevier Applied Science, London \& New York, pp. 92-126.

GRUDA, Z. \& POSTOLSKI, J. (1980): Gefrieren von Lebensmitteln. VEB Fachbuch-Verlag, Leipzig, pp. $49-62$.

HELDMAN, D. R. (1982): Food properties during freezing. Fd Technol., 36, (2), 92-97.

KOVAČEVIĆ, D. \& KURTANJEK, Ž. (1993): Odredivanje entalpije smrznutog iskoštenog ribljeg mesa (surimija) diferencijalnom termickom analizom. (Enthalpy determination of frozen surimi by differential thermal analysis.) Prehrambeno-tehnol. biotehnol. rev., 31, 157-164. 
LEE, C. M. (1984): Surimi process technology. Fd Technol., 38, (11), 69-72.

SCHWARTZBERG, H. G. (1976): Effective heat capacities for the freezing and thawing of foods. J. Fd Sci., 41, 152-156.

SCHWARTZBERG, H. G. (1983): Mathematical analysis of the freezing and thawing of foods - A compilation of readings and problems in food engineering. Univ. of Mass., Unpublished.

SyCh, J., LaCroiX, C., ADAmbOunOU, L. T. \& CASTAIGNe, F. (1990): Cryoprotective effects of lactitol, palatinit and polydextrose on cod surimi proteins during frozen storage. $J$. Fd Sci., 55, 356-360.

SWEAT, V. E. \& HAUGH, C. G. (1974): A thermal conductivity probe for small food samples. ASAE Trans., $17,(1), 56-58$.

SWEAT, V. E. \& HAUGH, C. G. (1976): A miniature thermal conductivity probe for foods. ASME Paper No. 76-HT-60, presented at ASME/AIChE Heat Transfer Conference, St. Louis, MO. 